University of Pennsylvania Carey Law School

Penn Carey Law: Legal Scholarship Repository

Faculty Scholarship at Penn Carey Law

$10-2022$

\title{
Negligence and Culpability: Reflections on Alexander and Ferzan
}

Mitchell N. Berman

University of Pennsylvania Carey Law School

Follow this and additional works at: https://scholarship.law.upenn.edu/faculty_scholarship

Part of the Criminal Law Commons, Ethics and Political Philosophy Commons, Law and Philosophy

Commons, Law Enforcement and Corrections Commons, Legal Theory Commons, and the Public Law and Legal Theory Commons

\section{Recommended Citation}

16 Crim. L. \& Phil. 455 (2022).

This Article is brought to you for free and open access by Penn Carey Law: Legal Scholarship Repository. It has been accepted for inclusion in Faculty Scholarship at Penn Carey Law by an authorized administrator of Penn Carey Law: Legal Scholarship Repository. For more information, please contact PennlawIR@law.upenn.edu. 


\title{
Negligence and Culpability: Reflections on Alexander and Ferzan
}

\author{
Mitchell N. Berman*
}

March 15, 2021

\begin{abstract}
Philosophers of criminal punishment disagree about whether infliction of punishment for negligence can be morally justified. One contending view holds that it cannot be because punishment requires culpability and culpability requires, at a minimum, advertence to the facts that make one's conduct wrongful. Larry Alexander and Kim Ferzan are prominent champions of this position. This essay challenges that view and their arguments for it. Invoking a conceptual distinction between an agent's being blameworthy for an act and their deserving punishment (or suffering) for that act, it explains that an agent can be blameworthy for negligent conduct, and thus liable to reasonable blaming practices, even if negligence is not culpable, hence not sufficient to ground negative desert. Turning from conceptual inquiry to substantive questions of political morality, it then argues that a faulty actor's lack of culpability does not render them immune from just punishment, but does significantly limit the severity of punishment that may be inflicted, for punishment should not be disproportionately severe relative to an agent's culpability in relation to wrongdoing.
\end{abstract}

\section{Introduction}

Few theses in criminal law theory enjoy wider support than that criminal punishment for strict liability offenses is unjust. The conclusion ordinarily follows from two premises. The first premise is one or another version of a responsibility-based constraint on justified criminal punishment-namely, that it is unjust to inflict punishment on actors who "don't deserve it" or "aren't blameworthy" or "lack culpability" or are "without fault" for the 
offense. ${ }^{1}$ The second premise maintains that agents who are actually and reasonably unaware of the facts that make their conduct wrongful lack the requisite responsibility-i.e., aren't culpable or blameworthy, or what have you.

And what about punishment for negligence? On this question, commentators who share the first premise-a premise central to almost all retributivist views, as well as to "side-constrained consequentialist" 2 theories-divide. Some affirm that an agent who is not in fact aware of necessary wrong-making features can exhibit the requisite type of responsibility when their lack of awareness was (in some sense) "unreasonable," when (in some sense) they "should have been aware" of what they weren't. Others deny this, insisting that punishment for negligence is just like punishment for strict liability and unjust for the same reason.

Larry Alexander and Kim Ferzan are among the most prominent and able defenders of the latter position. They unveiled their position a decade ago in their fascinatingly heterodox first co-authored volume, Crime and Culpability, ${ }^{3}$ and have now reiterated it in an equally provocative sequel, Reflections on Crime and Culpability: Problems and Puzzles. ${ }^{4}$ Their argument is straightforward. Here's my reconstruction:

\footnotetext{
* Leon Meltzer Professor of Law, the University of Pennsylvania Carey Law School, and Professor of Philosophy, the University of Pennsylvania. Email: mitchberman@law.upenn.edu. I am grateful to Massimo Renzo for inviting my contribution to this symposium on Larry Alexander and Kimberly Kessler Ferzan, Reflections on Crime and Culpability: Problems and Puzzles (2018), and to Larry and Kim, both for their challenging and entertaining book and for very helpful conversations and suggestions on this paper.

${ }^{1}$ A random sample of statements that use these varied locutions includes: Herbert Packer, Mens Rea and the Supreme Court, 1962 Sup. Cт. REv. 107, 109 (strict liability "is unjust because the actor is subjected to the stigma of criminal conviction without being morally blameworthy"); Douglas Husak, Strict Liability, Justice, and Proportionality, in A.P. SIMESTER ED., ApPraising Strict LIABILITy 81, 84 (2005) (noting the view that "liability without culpability [i]s especially unjust"); A.P. Simester, Is Strict Liability Always Unjust, in SIMESTER ED., supra, at 21 ("Convicting and punishing those who do not deserve it perpetrates a serious wrong."); Vera Bergelson, Does Fault Matter?, 12 CRIM. L. PHIL. 375, 384 (2018) ("punishment without fault" is "always unjust").

2 R.A. Duff, Punishment, Communication, And Community 11-13 (2001).

${ }^{3}$ Larry Alexander \& Kimberly Kessler FerZan, Crime and Culpability: A TheOry of CRIMINAL LAW ch.3 (2009)

4 Larry Alexander \& Kimberly Kessler Ferzan, Reflections on CRime and Culpability: Problems And PuZzLes 3-4 (2018). Alexander and Ferzan cite Michael Moore and Heidi Hurd, Neil Levy, and Jerome Hall as other proponents of this position. Id. at 3 n.10.
} 
(1) It is unjust to punish somebody for an act (including an omission) who doesn't deserve to be punished for it. ${ }^{5}$

(2) Nobody deserves to be punished for an $\operatorname{act}^{6}$ unless they were culpable for it.

(3) An agent's culpability for an act consists in their acting from an insufficient regard for legally protected interests deserving of respect.

(4) The fact and magnitude of an agent's insufficiency of regard is determined by the risks they were aware of and their beliefs in the existence of facts that would justify the incurring of such risks.

(5) An agent who is merely negligent for an act is, by definition, unaware of the facts that make their conduct wrongful.

(6) Therefore (from (3)-(5)), an agent who is merely negligent for an act lacks culpability for that act.

(7) Therefore (from (2) and (6)), merely negligent conduct does not render the agent deserving of punishment.

(C) Therefore (from (1) and (7)), it is unjust to punish somebody who is merely negligent.

I will argue, against Alexander and Ferzan, that punishment of negligent actors is at least sometimes permissible and consistent with the best understanding of the responsibility-based constraint on liability to justified punishment.

My counterargument is blessedly brief. I will accept, at least for sake of argument, premises (2) through (7). But I will deny premise (1). In its stead, I propose:

$(1)^{*}$ It is unjust to punish somebody for an act who isn't blameworthy for it.

Premises (1) and $(1)^{*}$ are alternative formulations of the responsibilitybased constraint on criminal liability that, in one version or another, is endorsed by an overwhelming majority of contemporary criminal law theorists. If that constraint is better formulated as (1)* than as (1), Alexander

\footnotetext{
${ }^{5}$ Alexander and Ferzan recognize that this premise might require some form of epistemic qualifier-e.g., that it is unjust to punish somebody whom you do not genuinely believe to deserve punishment. See, e.g., ALEXANDER \& FERZAN, supra note 3, at 8, 12-13. To simplify discussion, I omit such qualifiers throughout.

${ }^{6}$ Throughout, interpret "act" broadly to include, e.g., omissions or willings, as you wish.
} 
and Ferzan no longer have a valid argument for their proposed conclusion (C).

Of course, (C) could be true even if we substitute $(1)^{*}$ for (1). It all depends on whether blameworthiness, like negative desert, requires culpability (as that notion is construed in premises (3) and (4)). I will further argue that blameworthiness does not require culpability. My second premise is:

$(2)^{*}$ An agent can be blameworthy for an act despite being unaware

of the facts that make their conduct wrongful.

Therefore, I will conclude:

(C)* It can be just to punish somebody who is merely negligent. ${ }^{7}$

This argument consumes three short sections. Section 1, drawing on a companion paper, ${ }^{8}$ argues that negative desert and blameworthiness are distinct moral concepts that serve different normative functions: desert serves a favoring (or pro) function, whereas blameworthiness serves a liability function. Section 2 argues that an agent is blameworthy-i.e., is fairly liable to be subjected to reasonable blaming practices - when at fault, even when their fault is nonculpable. Extending that claim, Section 3 argues that an agent's liability to being punished for a faulty act (and not only to being blamed for it) also does not require that they had adverted to features of the act that would make them culpable. An agent can be morally liable, and thus subjected, to punishment (in virtue of their fault) even when (in virtue of their lack of culpability) they don't deserve it.

That's the core argument. But even if I'm correct that punishment of (merely) negligent actors is not always impermissible, ${ }^{9}$ that entails nothing about the severity of punishment that may justly be imposed for mere negligence. That's a lesson of Hart's distinction between two questions of

${ }^{7}$ I realize that this argument is not valid as formulated. That's easily fixed with an unless clause and an additional premise, but I hope you'll permit me this simplification to reduce clutter.

${ }^{8}$ Mitchell N. Berman, "Blameworthiness, Desert, and Luck" (unpublished ms., dated 12/30/20).

9 Alexander and Ferzan do not reject this claim if read strictly. As threshold deontologists, see ALEXANDER \& FERZAN, supra note 4, at 119 \& n.40, they would allow that knowing punishment of the merely negligent-like, for that matter, knowing punishment of the not-even negligent-is morally permissible if the costs of not doing so are sufficiently great. Let's put that aside. I'm discussing cases below the "threshold," wherever that may lie. 
punishment "distribution": "liability" and "amount."10 Section 4 contends that culpability does limit the severity of justified punishment thanks to a principle of proportionality that provides - to a first pass - that punishment should not be disproportionately excessive relative to an actor's culpability. Expanding briefly on that first pass, it ends with a few exploratory thoughts regarding the determinants of culpability. Dubbing Alexander and Ferzan's view (as reflected in premise (4)) that culpability is entirely a function of the agent's beliefs at a discrete moment of willing "culpability in wrongdoing," 11 it sketches a richer and more capacious notion meant to capture both the transtemporal character of culpability and its varying intensity. It calls this alternative picture "culpability in relation to wrongdoing."

\section{Blameworthiness and Desert as Distinct Moral Concepts}

Recall Alexander and Ferzan's initial premise, and the contrasting premise I have just proposed:

(1) It is unjust to punish somebody for an act who doesn't deserve to be punished for it; and

$(1)^{*}$ It is unjust to punish somebody for an act who isn't blameworthy for it.

These premises are not meaningfully different if to be blameworthy for an act (or willing) is the same thing as to deserve punishment (or some other negative treatment or state of affairs) ${ }^{12}$ for it. And that, I believe, is the

${ }^{10}$ H.L.A. Hart, Punishment and Responsibility: Essays In the Philosophy of LaW 11 (1968).

${ }^{11}$ Although they had previously described their view of culpability as a function of "risks and reasons," Alexander and Ferzan caution that that is a potentially misleading formulation for what is a sharply belief-focused account. ALEXANDER \& FERZAN, supra note 4 , at 2-3.

${ }^{12}$ For ease of exposition, I will drop this qualifying parenthetical going forward, and speak of whether an agent deserves punishment. But that will be shorthand for "deserves to be punished, or to suffer, etc." On the difference between these retributive desert objects, see Mitchell N. Berman, Two Kinds of Retributivism, in R.A. DufF AND STUART P. GREen EDS., PhilosophicAl Foundations OF CRIMINAL LAW 433 (2011).

My current view is that a wrongdoer deserves to experience their wrongdoing as personally costly to them or that, as Gideon Rosen puts it, a wrongdoer deserves to "suffer in recognizing what she has done." Gideon Rosen, The Alethic Conception of Moral Responsibility, in RandolPh Clarke, Michael McKenNa \& ANGELA M. SMith, THE NATURE OF MORAL RESPONSIBILITY: NEW ESSAYS 65, 86 (2015). Regardless of its precise formulation, the key insight is to conceptualize the retributive desert object as a downward departure from some 
dominant assumption, resting on "the familiar thought that blame is deserved by one who is blameworthy." 13 But however familiar, I believe that thought is mistaken. Valid desert claims carry significant normative force. And it's not the case that to be blameworthy renders an agent deserving of blame in that forceful sense. ${ }^{14}$

Think of morality as a system that establishes forward-looking norms regarding what we may, or must, do. At time $T_{n}$ it addresses agent $A$, enjoining them not to $\varphi$. Suppose that A flouts that injunction. What are the moral consequences of A's norm-violation? How, if at all, has A's (wrongful) ping altered the moral landscape, as far as A is concerned? How, if at all, do the rights, duties, powers and the like that make up A's "moral profile"15 change in virtue of A's $\varphi$ ing?

Consider three possibilities. First, in virtue of A's ping, A sometimes assumes or acquires new moral obligations - what are often termed "residual

existing or expected baseline of agential happiness or wellbeing, and not as some absolute or objective level of wellbeing. See Mitchell N. Berman, Rehabilitating Retributivism, 32 L. \& PHIL. 83, 87-88 (2013). A wrongdoer deserves to suffer in recognition, or deserves to experience their wrongdoing as personally costly, even if their level of wellbeing, prior to wrongdoing, were unjustly or unfairly low (which is not to prejudge whether the magnitude of deserved diminution in welfare is sensitive to pre-wrongdoing levels of wellbeing).

${ }^{13}$ Michael McKenna, Directed Blame and Conversation, in Justin D. COATES \& NeAl A. TOGNAZZINI, Blame: ITS NATURE AND Norms 119, 119 (2013).

14 Some readers have objected on the supposed semantic basis that deservingness of being blamed is baked into the word "blameworthy." But I think that reads the suffix "worthy" for more than it need be worth. While sometimes defined as "deserving of," it can also mean "suitable or safe for." That a vessel is seaworthy does not entail that it deserves to be put to sea in any favoring sense-either that there is intrinsic value in its being put to sea or that someone ought, or has reason, to put it to sea. It entails only that, if you have reason to put the vessel to sea, you can do so without committing a certain type of misstep. Likewise, for A to be blameworthy can mean only that at least some among a variety of ways of treating A that belong to the constellation of blaming behaviors-modes of treatment that would otherwise be unsuitable or inappropriate-are rendered suitable or apt. There is no agent, $B$, of whom it is true, simply in virtue of the fact that $A$ is blameworthy, that $B$ has even a (pro tanto) reason to blame A, just as there is no agent, B, of whom it is true, simply in virtue of the fact that a craft is seaworthy, that $B$ has a (pro tanto) reason to put the craft to sea. (This is not to prejudge whether B's reasons to engage in blaming activity could be partially grounded in the facts that ground the fact of A's blameworthiness.) In both cases, whether B should engage in the activity at issue (blaming A, putting the craft to sea) will depend upon reasons that are not grounded in the fact of A's blameworthiness, or of the craft's seaworthiness, as the case may be. This is not an argument that the semantics require the interpretation of blameworthiness that I offer. I'm observing only that semantics don't militate against an interpretation of blameworthiness that has greater theoretical virtuesnamely, enabling us to track two distinct normative functions that we should want and expect our normative concepts to serve.

${ }^{15}$ Mark Greenberg, The Moral Impact Theory of Law, 123 YALE L.J. 1288, 1308 (2014). 
duties" or "duties of repair." 16 A must apologize to those they have wronged, and try to repair any damage. And that duty of repair might entail a duty upon A to provide their victims with protection against wrongdoing by others. ${ }^{17}$ Maybe, in addition, A must reorganize their life to minimize the risk of reoffending. ${ }^{18}$ Second, A sometimes becomes liable to treatments by others that would be unfair to A, or would otherwise treat A wrongfully, but for A's ping. In a familiar way of putting things, A's wrongdoing might amount to a "forfeiture" of their rights against one or another form of disagreeable treatment. ${ }^{19}$ Third, in addition to making A liable to treatments to which A had been immune, A's ping could create new reasons for some agent or class of agents to subject A to such treatments, or could alter the non-instrumental impersonal value of states of affairs that involve A. Perhaps, for example, the state of affairs in which A experiences suffering or anguish would have been bad absent A's ping but now becomes less bad, or even good. ${ }^{20}$

In sum, A's wrongdoing can possibly ground at least three different, but not incompatible, moral consequences: A's ping grounds or activates duties imposed on A; A's ping grounds liability to treatment that, otherwise, would be unfair to A or would wrong A; A's ping grounds reasons to subject $\mathrm{A}$ to disagreeable consequences that would not otherwise obtain.

If I'm right that an agent's behavior can trigger these distinct moral consequences, the following thought suggests itself almost immediately: desert is or approximates our favoring notion and blameworthiness is or approximates our liability notion.

Take desert first. Although much about desert remains mysterious, that desert serves a "pro" or "favoring" function is close to common ground, where favoring is a catch-all term for conferring or enhancing the positive final value of a state of affairs or for grounding or intensifying noninstrumental reasons for action). That A deserves some treatment or state of affairs is not a normatively inert fact. It has normative force or significance, a significance often put in terms either of value or of reasons and duties. To a first pass, that $\mathrm{A}$ deserves some treatment increases the

${ }^{16}$ Philosophers debate whether A's $\varphi$ ing grounds a new duty or activates the antecedent of an existing conditional duty to which A was already subject. For my limited purposes, I believe and hope that we needn't choose between wide-scope and narrow-scope construals of the relevant duties.

17 Victor Tadros, The Ends of Harm: The Moral Foundations of Criminal LaW (2011).

18 Youngjae Lee, Recidivism as Omission: A Relational Account, 87 TeXas L. ReV. 571 (2009).

${ }^{19}$ See, e.g., Christopher Heath Wellman, The Rights Forfeiture Theory of Punishment, 122 ETHICS 371 (2012).

${ }^{20}$ See, e.g., LEO ZAIBERT, RethinKING PUNISHMENT (2018). 
impersonal value of the state of affairs in which that treatment obtains for A, or creates reasons of some stringency for some suitably situated others to bring that state of affairs about. ${ }^{21}$ That first-pass account of desert's normative force is desert-general: it applies across the waterfront of valid desert claims regardless of their contents. If "negative" or "retributive" desert is part of our moral system - if individuals ever deserve to experience disagreeable consequences or to suffer harsh treatment in virtue of their misbehavior - then that truth combined with general truths about desert's normative significance entails that it is noninstrumentally impersonally good that wrongdoers receive their deserved consequences, or that some properly situated others have affirmative reason or obligation to cause those consequences or treatments to obtain.

If desert captures the favoring notion of individual responsibility, it is natural to suppose that blameworthiness captures the liability notion. If for A to have negative desert for $\varphi$ ing is for it to be the case that some negative or harsh treatment of $A$ that would otherwise be disfavored or forbidden is now favored, for A to be blameworthy for $\varphi$ ing is for it to be the case that A is now liable to a range of "blaming practices" involving directed criticism, censure, castigation, distancing, retaliation, infliction of costs or hardship, punishment, and the like, to which A would otherwise be immune..$^{22}$ Is this even intelligible? Could some party, B, have any reason to subject $\mathrm{A}$ to the treatments to which they liable that is not a reason grounded in the fact that such treatments are now (non-instrumentally) favored? Of course. B's harsh treatment of A might serve to discourage others from ping, or to satisfy B's anger or retaliatory impulses, among other ends.

That blameworthiness is a more modest upshot than desert is apparent from fundamental debates over the justifiability of punishment. Although many commentators have discerned a retributivist revival, many philosophers think it barbaric. Why? Precisely because the notion of desert it deploys is a favoring notion: A's culpable wrongdoing grounds an alteration in the impersonal noninstrumental value of A's suffering (or being punished, or what-have-you), or grounds noninstrumental reasons for us to inflict punishment, or visit suffering, upon A. It is desert's favoring character that causes many anti-retributivists to deny that negative desert

${ }^{21}$ I aim to be agnostic regarding which normative concept, good and reason, is passing the buck to the other.

${ }^{22}$ This is not to say that the treatment at issue is rendered permissible all things considered; it's to say that a certain type of especially salient and forceful barrier to the treatment is erased, canceled, or overridden. 
exists. ${ }^{23}$ At the same time, anti-retributivists will more readily accept that wrongdoing (partially) grounds blameworthiness, understood as a liability concept. It better, else responsibility-based side constraints on instrumentalist goals would be in jeopardy. Finally, and not coincidentally, this way of distinguishing the concepts helps explain and vindicate the idea that it is desert, not blameworthiness, that is really threatened by causal determinism. ${ }^{24}$

\section{The Ground of Blameworthiness: Fault, not Culpability}

Substituting my proposed premise $(1)^{*}$ for Alexander and Ferzan's premise (1) makes a difference to the debate over criminal liability for negligence only if the grounds or determinants of blameworthiness and desert differ. I contend that they do. In broad strokes, I agree with Alexander and Ferzan (premise (2)) that an agent deserves punishment for an act only if culpable for it, i.e., that culpability forms all, or an ineliminable part, of the retributive desert base. I also agree (premise (3)), that culpability consists in morally insufficient concern or regard. (I will expand on this notion, differing from Alexander and Ferzan at the level of detail, in Section 5.) But culpability is not required to render an agent blameworthy. An agent is made justly liable to being blamed by being at fault. And one is at fault for failing to conform to a fair standard fairly imposed.

Lacking a detailed argument for this claim, or space for it, I'll offer three supportive observations. Start by reflecting on our ordinary lives. In many contexts, we blame one another for failing, even nonculpably, to satisfy standards of conduct. We blame our kids for violating house rules. We blame drivers who run into us due to inattention or poor driving skills. We blame friends and lovers for slights and forgetfulness. Saints fans blame referee Bill Vinovich and his officiating crew for missing a pass-interference call that would have sent New Orleans to the Super Bowl. Whether we're blaming or being blamed, these practices strike few of us as categorically misguided, even if we might often conclude that a given blaming episode was mistaken or excessive in duration or severity.

Second, that an agent can be fairly liable to blame absent culpability also makes sense of a common practice in which a CEO or other institutional

${ }^{23}$ See, e.g., TADros, supra note 17. Anti-retributivism encompasses a broad array of attitudes about desert and conceptions of its workings. Not all anti-retributivists reject negative desert tout court.

${ }^{24}$ See, e.g., Derk Pereboom, A Notion of Moral Responsibility Immune to the Threat from Causal Determinism, in CLARKE, MCKENNA \& SMITH, supra note 12, at 281. 
leader "takes full responsibility" for a mess-up for which that leader was not personally at fault. By taking responsibility, an agent renders themself liable to blaming practices, including a society's public shaming rituals, as though they were at fault. But the agent does not thereby attract retributive desert, as though they were culpable.

Third, the very fact that desert and blameworthiness bear different normative upshots - desert is a favoring notion while blameworthiness is a liability notion-suggests the likelihood that they'll have different determinants. If given behavior can give rise to different normative consequences, it's only to be expected that the triggers for the different normative consequences should themselves differ. One might say that morality would be missing an opportunity if the triggers were all the same. ${ }^{25}$

To summarize my proposed analyses of the relevant concepts:

DESERT: What it is for an agent, $\mathrm{A}$, to deserve some treatment or state (A's desert object) because of some conduct or quality of A's (A's desert base) is for it to be impersonally non-instrumentally good that A get that treatment or state, or for some agent(s) to have (special or stringent) reason to bring that treatment or state about, in virtue of A's conduct or quality.

CULPABILITY: What it is for an agent, A, to be morally culpable for conduct is for that conduct to issue from A's insufficient regard for the interests of others, and thereby to instantiate a morally objectionable quality of will. (Culpability is all or part of the desert base for retributive desert.)

BLAMEWORTHINESS: What it is for A to be blameworthy for some conduct, event, or state is for A to be at fault with regard to that conduct, event, or state, and thereby to be rendered liable to reasonable blaming practices (by some agent(s)) to which A would otherwise be morally immune.

FAULT: What it is for A to be at fault with regard to some conduct, event or state is for A to engage in that conduct, or to allow that event to occur or state to obtain, in consequence of A's failure to satisfy a fairly imposed standard.

${ }^{25}$ Alexander and Ferzan consistently treat desert as serving both favoring and liability functions. See, e.g., AlEXANDER \& FERZAN, supra note 3, at 6-7 ("In our view, it is the defendant's decision to violate society's norms regarding the proper concern due to the interests of others that establishes the negative desert that in turn can both justify and limit the imposition of punishment.") That's the assumption that lets them move from the claim that desert requires culpability to the conclusion that liability requires culpability. 


\section{The Permissibility of Punishment Without Culpability}

Suppose that what I've argued thus far is correct: an agent is liable to blame by being at fault, even when nonculpable. Alexander and Ferzan could accept this claim and still preserve their position on criminal liability for negligence, by maintaining that an agent is liable to punishment (an especially severe type of blame) only when culpable (an especially serious type of fault). I'll read this as a first-order claim about political morality not as claim about the relevant moral concepts. ${ }^{26}$ That is, while I contend it is true of our concept BLAMEWORTHINESS that to be blameworthy is to be morally liable, in virtue of one's being at fault, to blaming practices to which one would otherwise be morally immune, I deny that the claim now under consideration-i.e., that liability to punishment requires culpability - is baked into our concepts, even though it might be a compelling contention of justice or political morality.

Is it? Again, I have no decisive argument against that possibility. But, and also again, here are diverse considerations that counsel doubt.

First are casuistic intuitions. A ship's captain, or a truck driver or train engineer, due to gross negligence (but not recklessness), causes an accident with substantial loss of life. A police officer involved in a shooting episode forgets to turn on their body camera as required by state law. A criminal defense attorney fails to file a timely appeal, paving the way for their client's execution. A childcare provider leaves their young charge in the bath or in a hot car "just for a moment" with tragic results. Many or most people will think it just, even on reflection, to inflict modest criminal punishmentweekend house confinement, community service, etc. - in some such cases.

Second, punishability without culpability gains support from a powerful theoretical account of excuses: John Gardner's view that " $t]$ he gist of an excuse ... is precisely that the person with the excuse lived up to our expectations," which is to say that they lived up to the standards to which

${ }^{26}$ It could be otherwise. Many thinkers hold that it is part of the nature of punishment that it express moral condemnation, in which case an act of punishment is fitting or successful only when the punishing authorities believe the agent condemnable, which requires culpability (or in any event something more than the mere fault that licenses noncondemnatory forms of blame). I agree that the standard case of punishment involves expression of condemnation. But it doesn't follow that every sanction that an institution of criminal punishment inflicts must be condemnatory or must presuppose that the patient on whom the sanction be inflicted is condemnation-liable. And I deny those latter claims. But if you think that the infliction of disagreeable consequences with the intention that they be experienced as disagreeable does not count as punishment unless married to moral condemnation, call such non-condemnatory inflictions "shmunishment." The question addressed in this section is whether shmunishment requires culpability. 
a person in their role should conform. ${ }^{27}$ As Gardner further explains, "the law has a function not only in supporting, but also in establishing, the proper standards of character ... for the roles it governs," standards such as "[ $t]$ he measure of attentiveness required of drivers," ${ }^{28}$ and the degree of courage and level-headedness required of persons in public safety positions. As these two examples suggest, persons who inhabit these roles can fail to satisfy at least some governing standards nonculpably. When they do, they lack an excuse, reasons Gardner, and are thus often properly punished.

Third, this combination of claims - that criminal liability is conditioned on blameworthiness, not on desert, and that blameworthiness requires only fault, not also culpability - fits well with the harm-reduction rationale that many theorists believe explains and justifies the institution of criminal punishment. Two prominent and familiar philosophers of the criminal law (wink) have expressed that view well:

Ultimately, what underlies the criminal law is a concern with harms that people suffer and other people cause-harms such as loss of life, bodily injury, loss of autonomy, and hart to or loss of property. The criminal law's goal is not to compensate, to rehabilitate, or to inculcate virtue. Rather, the criminal law aims at preventing harm. ${ }^{29}$

Plainly, people's awareness that their negligent conduct might make them liable to criminal punishment can induce them to take greater care or precautions, thereby reducing social harms. And it is hardly obvious that punishment for negligence is unfair so long as the behaviors to which negligence liability attaches are reasonably avoidable or the circumstances that ground punishment without culpability are ones to which reasonable agents could agree in a suitably described choice situation.

Fourth, this account holds promise to help solve puzzles surrounding the punishment of persons who are morally negligent. In Reflections, Alexander and Ferzan deem "[t]he problem of moral ignorance ... perhaps the greatest challenge to [their] theory of criminal law and to any other retributive theory." ${ }^{30}$ The problem is implicated in three distinct types of cases: punishment of psychopaths, punishment of "ordinary criminals" who get morality wrong, and punishment of persons who violate our moral norms and laws out of obedience to a different moral system, such as, in Alexander and Ferzan's example, one that recommends or requires honor

\footnotetext{
${ }^{27}$ John Gardner, The Gist of Excuses, 1 Buffalo CRIM. L. Rev. 575, 578 (1998).

${ }^{28} I d$. at 594 .

${ }^{29}$ AlEXANDER \& FERZAN, supra note 3 , at 3.

${ }^{30}$ AlEXANDER \& FERZAN, supra note 4 , at 107.
} 
killings. I'll focus on this third category, one that often provokes questions about the propriety of a "cultural defense."

The reason to believe "that the honor killer is not culpable" is that, unlike the psychopath and the ordinary criminal, the honor killer does not obviously give the interests of others insufficient regard. ${ }^{31}$ To the contrary, "the honor killer may generally give others' interests great weight, and he may regard the honor-mandated necessity of killing his victim with deep regret and as an extreme sacrifice of his own interests." 32 Thus, Alexander and Ferzan conclude, "the blameworthiness of the honor killer" is in grave doubt. $^{33}$

Notice that, as in their discussion of negligence, Alexander and Ferzan treat "culpability" and "blameworthiness" synonymously. I would not. I'd conclude that the honor killer is blameworthy because plainly at fault. The fault lies in not complying with legal and moral rules of the agent's place. It is fair to be required to comply with the legal and moral requirements of the community in which you find yourself. Therefore, the honor killer is liable to blaming practices, including punishment so long as there are good reasons to punish, as of course there are.

\section{Punishment Severity and Principles of Proportionality}

That it is (sometimes) morally permissible to blame and to punish actors for nonculpable faults does not resolve how much blame or punishment is permissible. I have argued elsewhere that to be at fault renders one liable to "reasonable" blaming practices, that many considerations bear on what is (or is not) reasonable, and that it is not possible to precisify the reasonable very far. ${ }^{34}$ How much and in what way an agent may fairly be blamed for faulty conduct, in ordinary life as well as in more institutionalized contexts, is informed by such diverse considerations as the agent's background and upbringing and the breadth of their opportunities to avoid wrongdoing; the consequences of the agent's wrongdoing; whether they had done it before; the treatment accorded other, similarly situated faulty actors; the "standing" of those who would impose blame; and the likelihood that a

${ }^{31} I d$

${ }^{32} \mathrm{Id}$. at 106 .

${ }^{33} \mathrm{Id}$. at 107.

${ }^{34}$ See Berman, "Blameworthiness, Desert, and Luck," supra note 8 (manuscript, at 13-16) (distinguishing between the severity of blame to which one is liable, and the extent to which one is liable to that blame). 
strong response would have a positive effect on future behavior by this agent or by similarly situated others; and more.

If this is broadly correct, a significant worry arises. Imagine a case in which an agent's nonculpable fault produces grave harms. A careless hiker starts a forest fire. A negligently manufactured product causes scores of deaths. An executive's forgetfulness enables a massive data breach. If the public's anger has been greatly aroused, if a harsh response could be expected to significantly deter similar future acts, if the social benefits of realizing that significant deterrence are substantial, then the infliction of severe punishment will emerge as all-things-considered reasonable at least sometimes. It could be all-things-considered reasonable, not irrational or pointlessly cruel, to punish an individual severely despite their lack of culpability. ${ }^{35}$ The broad scholarly enthusiasm for principles of proportionality in punishment can be understood, in large measure, as a response to this possibility and others like it. As is true of proposed constraints on liability to punishment (see Section 3), these principles are not, in my judgment, built into any of our relevant moral concepts, such as BLAMEWORTHINESS or PUNISHMENT. Rather, they are first-order principles of political morality that theorists either view as already embedded in our criminal justice practices or propose that our legal systems should adopt. Perhaps the most commonly defended principle holds that punishment should be proportional either to the offender's culpability alone, or to some amalgam of the offender's culpability and the harm that their culpable conduct caused.

I am sympathetic to a principle in this neighborhood. This leaves me close to Alexander and Ferzan's position, but subject to one reminder and three caveats. The reminder is that proportionality governs punishment severity; accepting culpability as a constraint on the severity of just criminal punishment is consistent with rejecting culpability as a precondition on criminal liability. Now the caveats. First, this principle condemns punishments that are disproportionately severe, but not those that are disproportionately lenient. It is a "ceiling" principle not a combination of ceiling and "floor" principles, i.e., a "bracket" principle. ${ }^{36}$ Second, this is a

${ }^{35} \mathrm{I}$ 'm assuming that punishment severity is measured in (something like) "hardness of treatment." I don't deny that it might be irrational or pointlessly cruel (or misguided in some other profound way) to condemn somebody severely for nonculpable actions.

${ }^{36} \mathrm{I}$ introduce this distinction in Proportionality, Constraint, and Culpability, _ CRIM. L. PHIL. __ (forthcoming). Alexander makes clear that he endorses a bracket principle of proportionality in Larry Alexander, Proportionality's Function, _ CRIM. L. PHIL. _ (forthcoming). 
principle - a weighty contributory notion ${ }^{37}$ - not a cap. It bears forcefully against punishments that are disproportionately severe relative to the agent's culpability, without purporting to flatly prohibit them. Third, putting aside whether harm, not only culpability, contributes to the proportionality base (or to the retributive desert base, for that matter), ${ }^{38} \mathrm{I}$ don't share Alexander and Ferzan's austere view of culpability's determinants.

Let me say a few words, necessarily suggestive and exploratory, on this last score before concluding. Alexander and Ferzan's formal and explicit "position is that the culpability that grounds retributive desert is constituted by two things." 39 Those two things are "what the actor believes regarding the nature and consequences of his conduct (and the various probabilities thereof) and what the actor's reasons are for acting as he does in light of those beliefs." 40 Put another way, culpability is a "function" or "product" of two factors: the magnitude of agentially risked harms (itself a product of the magnitude of the harms that the agent foresees discounted by the probability the agent assigns to the prospect that their conduct will cause those harms to be realized), and the value or worth of the reasons that the agent recognizes as bearing in favor of the conduct they engage in, all determined at the moment of the agent's willed bodily movement that, in the agent's estimation, "unleashes" the risks. ${ }^{41}$ Alexander and Ferzan

${ }^{37}$ On the crucial distinction in normative theory between decisive and contributory notions see Errol Lord \& Barry Maguire, An Opinionated Guide to the Weight of Reasons, in ERrol Lord \& BARry Maguire eds, Weighing ReAsons 3 (2016). For my argument that Ronald Dworkin's famous but somewhat obscure rules/principles distinction (see Ronald Dworkin, The Model of Rules, 35 U. CHI. L. REV. 14 (1967), reprinted and revised as The Model of Rules I, in RONALD DWORKIN, TAKING RIgHTS SERIOUSLY ch. 2 (1977)) is best understood as anticipating the decisive/contributory distinction, see Mitchell N. Berman, "Toward Principled Positivism: Revisiting the Start of the Hart-Dworkin Debate" (ms, dated May 24, 2020).

${ }^{38}$ I examine this nettlesome question in Berman, "Blameworthiness, Desert, and Luck," supra note 8 .

${ }^{39}$ AlEXANDER \& FERZAN, supra note 4 , at 2.

${ }^{40}$ AleXANDER \& FERZAN, supra note 3 , at 41.

${ }^{41}$ In my judgment, Alexander and Ferzan's contention that an agent who intends harm to others does not engage in a culpable action prior to the last act that (as the agent views it) unleashes a risk of harm to a legal protected interest, $i d$. at ch.5, is unsound. Take an example I offered the authors previously: D is considering traveling from Philly to L.A. to kill D's nemesis, V. E advises D not to kill V. E specifically urges D not to board the plane. E says "if you board that plane, you might or might not choose to (try to) kill V; if you don't get on that plane, you won't have the opportunity to kill V." D replies: "You speak the truth." D then boards the plane. AlEXANDER \& FERZAN, supra note 4, at 38 \& n.58. To be sure, "actors can still change their minds, even after they have taken substantial steps." But this truth is nowhere near the "decisive objection" that Alexander and Ferzan take it to be. ALEXANDER 
assume that these two factors can be assigned commensurable values and that an agent's culpability for an action is some function, probably additive, of these two values. Although a function of two factors, then, culpability is, like the area of a two-dimensional figure, a one-dimensional scalar.

In my competing view, culpability is not solely a function of beliefs held concurrent with the willed bodily movements that (from the actor's perspective) impose risks of harm to protected interests. I think that the determinants of culpability include more than solely cognitive states, that culpability is a function of the agent's attitudes toward wrongs and not only toward harms, and that cognitive and non-cognitive states that bear on an actor's culpability for wrongdoing are not only those that coincide with the willings that are part of the actus reus of an offense. That mens rea and actus reus must be concurrent for criminal liability to attach does not entail that the measure of an agent's culpability that matters to just punishment is the culpability that is determined by beliefs coincident with the wrongful act. Culpable attitudes that concern the act need not be co-occurrent with it to bear on the agent's culpability in relation to the act, without collapsing into a character theory of culpability. I intend the phrase "culpability in relation to wrongdoing" to capture this broader notion, vague though it undoubtedly is. ${ }^{42}$

\& FERZAN, supra note 3, at 212. For while actors can change their minds, and can be aware of that fact, they can also be aware of the fact that they might not change their minds. That's all that's needed to establish that $\mathrm{D}$ is culpable when boarding the plane because their willed bodily movement subjectively increases the risk of harm to V.

Or does it? Alexander and Ferzan next object that "one cannot regard one's own future conduct that will be fully under the control of one's reason and will as a risk that one's present conduct is imposing." Id. at 214. But that is false. One can regard one's future conduct as a risk, and we do it all the time. Somebody who believes that a little ice cream would be good but that a lot of ice cream would be bad sometimes doesn't buy ice cream at the market because they foresee a risk that they'll later eat a lot rather than a little. The bottom line is this. While I wouldn't exclude the possibility that Alexander and Ferzan could marshal colorable arguments of political morality for the proposition that a liberal state should not punish persons for incomplete attempts, their contention that incomplete attempts are necessarily not culpable is incorrect on their own theory of culpability.

${ }^{42}$ Having pointed toward a broader notion of culpability than Alexander and Ferzan's beliefs-only account, let me acknowledge that even they depart from that account in perhaps two respects. First, they do allow, late in their exposition, that "culpability includes the quality of the actor's decision making. We contend that when an actor's decision making is degraded, the actor is less culpable. Conversely, in some instances, enhanced decisionmaking quality can aggravate culpability." Id. at 256 (citing Kimberly Kessler Ferzan, Holistic Culpability, 28 CARDOZO L. Rev. 2523, 2534 (2007)). Second, in a sole-authored article contemporaneous with Crime and Culpability, Ferzan acknowledges that "[a] second constitutive aspect of an actor's culpability is her psychological feeling about the harm she is imposing," and cautions that "while we can describe risks and reasons in mechanical 


\section{Conclusion}

On the view I've advanced here, it is unjust to punish agents who have not made themselves liable to blame (and thus to punishment) by dint of their faulty conduct. Ceteris paribus, it is not unjust to punish agents who have. But one can be at fault without exhibiting the ill will toward others, or insufficient concern for morally weighty interests, that constitutes culpability. Because inadvertence can be faulty even when not culpable, it is not categorically unjust to punish for nonculpable negligence.

Yet if culpability is not a necessary condition on the just imposition of punishment, it does sharply constrain the severity of punishment that the state may justly inflict. I share the judgment of many theorists that the state may not impose punishment excessively severe in proportion to the agent's culpability. The upshot is that, although punishment for nonculpable negligence is sometimes permissible, on my view, the punishment inflicted can only be mild even when sound reasons weigh for severe punishment.

And how should we understand this culpability that constrains the infliction of otherwise-reasonable punishments and that, for retributivists, forms all or part of the retributive desert base? I cannot offer anything even approaching a complete answer to that profound question in this short essay. I have contended, however, that culpability is not fully reducible to the belief calculus that Alexander and Ferzan defend. It is a phenomenologically richer, more textured, and temporally extended notion to which the phrase "culpability in relation to wrongdoing" gestures.

terms, we should not ignore the affective aspects of practical reasoning." Ferzan, Holistic Culpability, supra, at 2534. I am not entirely sure what to make of these passages. It's not clear to me what counts in decision-making "quality" for Alexander and Ferzan and, just as importantly, what doesn't. Furthermore, as far as I can tell, Alexander and Ferzan do ignore affective aspects of practical reasoning, and an actor's "feeling" about the harms their action risks is actually no part of their official account of the constituents of culpability.

My possible misunderstandings aside, what is clear is that to the extent their theory of culpability really does allow culpability to be sensitive to the quality of an agent's decision making or to their affective states, it is no longer the austere beliefs-only theory that Alexander and Ferzan advertise. Degraded or enhanced decision making are not themselves beliefs. If characteristics regarding the manner in which the beliefs that matter are produced are independent determinants of the agent's culpability, then it is no longer the case that culpability is a product only of the agent's beliefs. 